„TURYZM”, t. 7, z. 2, 1997

Bogdan Wlodarczyk

KSZTAŁCENIE KADR TURYSTYCZNYCH NA POZIOMIE WYŻSZYM W ZAKRESIE OCHRONY PRZYRODY NA PRZYKLADZIE SPECJALNOŚCI Z GEOGRAFII TURYZMU I HOTELARSTWA W UNIWERSYTECIE ŁÓDZKIM

LA FORMATION DES CADRES TOURISTIQUES AU HAUT NIVEAU DANS LE DOMAINE DE LA PROTECTION DE LA NATURE; EXAMPLE: LA SPÉCIALISATION DANS LE DOMAINE DE LA GÉOGRAPHIE DU TOURISME ET DE L'HÔTELLERIE À L'UNIVERSITÉ DE ŁÓDŹ

HIGHER EDUCATION OF TOURISM PERSONEL IN NATURE PROTECTION, ON THE EXAMPLE OF THE DEPARTMENT OF THE GEOGRAPHY OF TOURISM AND HOTEL MANAGEMENT AT THE UNIVERSITY OF ŁÓDŹ

Wszelkie dyskusje nad programami studiów wyższych z zakresu turystyki zazwyczaj kończą się stwierdzeniami podkreślającymi interdyscyplinarność tej części wiedzy. Według fachowców wykształcony menedżer turystyki wyposażony winien być w szeroki zakres wiedzy i umiejętności, pozwalający jak najlepiej organizować i promować turystykę. W dobie coraz większego zainteresowania, a może nawet swoistej mody na formy turystyki przyjaznej środowisku naturalnemu zastanowić się trzeba, jak wygląda kształcenie w polskich uczelniach wyższych w zakresie ochrony przyrody, czy też turystycznego wykorzystania obszarów chronionych.

Poruszany problem staje się o tyle ważny, że w Polsce bardzo szybko powiększa się powierzchnia obszarów podlegających ochronie (tab. I.) W nowo powstałych parkach narodowych, krajobrazowych, czy obszarach chronionego krajobrazu (w nieco mniejszym stopniu) często dochodzi do sytuacji konfliktowych w relacji obszar chroniony - turystyka. Paradoksalnie, powołanie nowego parku narodowego czy krajobrazowego, pomimo wszelkich ograniczeń wynikających z tego faktu oraz braku zmian w środowisku przyrodniczym, kulturowym i infrastrukturze turystycznej, powoduje, że obszar ten zostaje zauważony przez potencjalnego turystę i staje się w jego oczach bardziej atrakcyjny. Dlatego tak 
Obszary podlegające ochronie w Polsce w latach 1980-1996

Les terrains protégés en Pologne dans les années 1980-1996

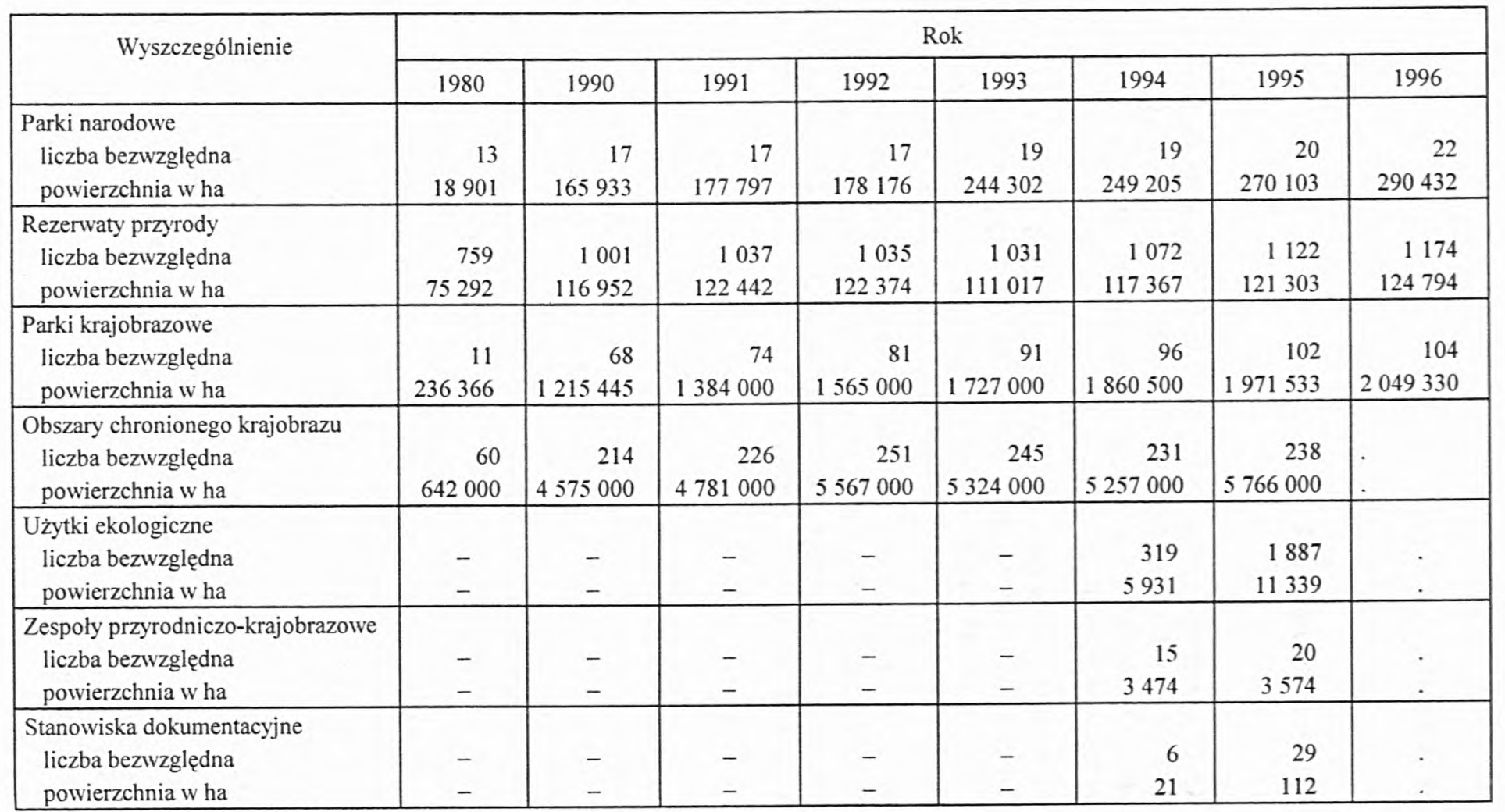




\begin{tabular}{|c|c|c|c|c|c|c|c|c|}
\hline $\begin{array}{l}\text { Lasy ochronne } \\
\text { liczba bezwzględna } \\
\text { powierzchnia w ha }\end{array}$ & $\begin{array}{c}1739000 \\
-\end{array}$ & $\begin{array}{c}2679000 \\
-\end{array}$ & $\begin{array}{c}2807000 \\
-\end{array}$ & $\begin{array}{c}2920000 \\
-\end{array}$ & $\begin{array}{c}3214000 \\
-\end{array}$ & $\begin{array}{c}3312000 \\
-\end{array}$ & $\begin{array}{c}3312000 \\
-\end{array}$ & . \\
\hline $\begin{array}{l}\text { Leśne kompleksy promocyjne } \\
\text { liczba bezwzględna } \\
\text { powierzchnia w ha }\end{array}$ & - & - & - & - & $\begin{array}{l}- \\
-\end{array}$ & - & $\begin{array}{r}6 \\
324000 \\
\end{array}$ & $\dot{-}$ \\
\hline Suma powvierzchni (w ha) & 2811559 & 8652330 & 9272239 & 10352550 & 10620319 & 10805498 & 11779964 & . \\
\hline Odsetek powierzchni Polski & 8,99 & 27,67 & 29,65 & 33,10 & 33,96 & 34,56 & 37,63 & . \\
\hline Na 1000 ludności (w ha) & 78,68 & 226,60 & 242,03 & 269,47 & 275,81 & 280,07 & 309,90 & . \\
\hline
\end{tabular}

Ź r ó d ł o: Rocznik statystyczny GUS (lata 1990-1996); Obszary chronione w Polsce, Instytut Ochrony Środowiska 1996, obliczenia własne. 
ważnym wydaje się kształcenie przyszłych organizatorów i menedżerów turystyki w kierunku racjonalnego wykorzystywania zasobów przyrody. Tylko znajomość form ochrony przyrody oraz praw i przepisów związanych z ich funkcjonowaniem może zapobiec nowym konfliktom interesów między gospodarzami terenów chronionych a turystami. Dotyczy to zarówno szeroko rozumianej edukacji ekologicznej polskiego społeczeństwa, jak i - w równym stopniu - wszystkich podmiotów zajmujących się organizacją turystyki.

W terminologii turystycznej pojawiają się nowe określenia, w znaczeniu których dopatrzeć można się treści związanych z poruszanym tematem. Są to m.in.: ekoturystyka czy też turystyka ekologiczna, turystyka zrównoważona, turystyka prośrodowiskowa. Pomimo różnic $\mathrm{w}$ interpretacji poszczególnych pojęć w różnych ośrodkach akademickich i braku w tym względzie jednolitości i precyzji terminologicznej, wspólną ich cechą jest podejście charakteryzujące się brakiem negatywnych relacji: turystyka-środowisko przyrodnicze. Zarówno wielość terminów, jak i tytułów przedmiotów realizowanych na poszczególnych uczelniach (m.in. ekoturystyka, dziedzictwo przyrodnicze w turystyce, ochrona środowiska przyrodniczego w turystyce) świadczy o dużym zainteresowaniu kształceniem w tym zakresie na wielu uczelniach. Niestety, nie dotyczy to wszystkich szkół wyższych prowadzących edukację w zakresie turystyki (tab. II). Braki te moga

T a b e l a II

Kształcenie w zakresie ochrony środowiska dla potrzeb turystyki w wybranych uczelniach wyższych w Polsce

L'enseignement dans le domaine de la protection du milieu pour assouvir les besoins du tourisme dans les écoles supérieures choisies en Pologne

\begin{tabular}{|l|c|l|c|}
\hline \multicolumn{1}{|c|}{ Uczelnia } & $\begin{array}{r}\text { Liczba } \\
\text { godzin }\end{array}$ & \multicolumn{1}{|c|}{ Uczelnia } & $\begin{array}{r}\text { Liczba } \\
\text { godzin }\end{array}$ \\
\hline Uniwersytet Gdański & 30 & AWF Kraków & 38 \\
Uniwersytet Jagielloński & 30 & AWF Poznań & 36 \\
Uniwersytet Lódzki & 160 & AWF Warszawa & 37 \\
Uniwersytet Wrocławski & 24 & AWF Wroclaw & 13 \\
AE Kraków & 12 & WSM Gdynia & 0 \\
AE Poznań & 30 & WSP Rzeszów & 120 \\
AE Wrocław & 45 & GWSH Katowice & 45 \\
SGH Warszawa & 30 & PSBSW Kraków & 60 \\
AWF Gdańsk & 31 & WSE Warszawa & 45 \\
\hline
\end{tabular}

${ }^{a}$ Wyższe szkoly zawodowe.

Ź r ó d l o: Ksztalcenie kadr turystycznych na poziomie wyższym a potrzeby rynku turystycznego. Materiaty z konferencji w dniach 28-29.10.1996 w Centrum Edukacji Kadr Turystycznych w Krakowie.

Uwaga. W wykazie uwzględniono tylko te przedmioty, których nazewnictwo wyraźnie sugeruje podejmowane treści. Godziny poświęcone poruszanemu zagadnieniu realizowane w ramach innych przedmiotów nie zostały objęte niniejszą statystyką. 
być spowodowane wąską specjalizacją poszczególnych kierunków, a przedstawiony obraz zniekształcony jest niekompletnością informacji zawartych w programach nauczania prezentowanych przez poszczególne uczelnie.

Zajęcia kameralne składają się zasadniczo $\mathrm{z}$ trzech odrębnych grup przedmiotów. Pierwsza obejmuje elementy wiedzy niezbędne do zdobycia uprawnień strażnika ochrony przyrody (szczegółowy wykaz przedmiotów w tab. III). Druga to przedmioty poruszające problemy ochrony środowiska przyrodniczego $\mathrm{w}$ turystyce. Studenci mogą tu wybrać profil przyrodniczy bądź ekologiczny.

T a b e I a III

Przedmioty na specjalności geografia turyzmu i hotelarstwa w Uniwersytecie Łódzkim, w ramach których realizowane są treści związane $\mathrm{z}$ ochroną przyrody

Les matières enseignées aux étudiants en géographie du tourisme et de l'hôtellerie à l'Université de Łódź abordant les problèmes de la protection de la nature

\begin{tabular}{|c|l|c|}
\hline $\begin{array}{c}\text { Rok } \\
\text { studiów }\end{array}$ & \multicolumn{1}{|c|}{ Nazwa przedmiotu } & $\begin{array}{c}\text { Liczba } \\
\text { godzin }\end{array}$ \\
\hline I & $\begin{array}{l}\text { Ochrona środowiska przyrodniczego w turystyce } \\
\text { (profil przyrodniczy lub ekologiczny - do wyboru) } \\
\text { Kurs Strażnika Ochrony Przyrody (obligatoryjnie) } \\
\text { Organizacja ochrony środowiska w Polsce } \\
\text { Zagadnienia prawne (prawo: wykroczeń, lowieckie, wędkarskie) }\end{array}$ & 20 \\
& Formy ochrony przyrody w Polsce & 36 \\
& Ochrona gatunkowa roślin & \\
& Ochrona gatunkowa zwierząt & \\
& Dendrologia & \\
& Ekologiczne podstawy ochrony przyrody & \\
& Zajęcia praktyczne w rezerwatach regionu lódzkiego & \\
& Wyjazd studialny do Kampinoskiego PN & \\
& Egzamin praktyczny & \\
& Praktyki specjalnościowe - park narodowy & \\
& Geografia fizyczna kompleksowa (Świętokrzyski PN)* & 60 \\
& Region turystyczny Polska Pn. (Slowiński PN)* & 36 \\
\hline II & Walory przyrodnicze w turystyce (do wyboru) & 20 \\
& Region turystyczny Polska Pd. (PPN, TPN, OPN, MPN)* & 36 \\
& Regiony turystyczne Europy* & 42 \\
\hline III & Ćwiczenia terenowe, przedmiotowe z geografii turyzmu i hotelarstwa* & 84 \\
\hline \multirow{2}{*}{ Razem } & Obligatoryjnie & 160 \\
& Częściowo & 258 \\
\hline
\end{tabular}

Ź r ó d ł o: Program i plan nauczania na kierunku geografia, specjalność geografia turyzmu i hotelarstwa.

Uwaga. W przedmiotach oznaczonych * tylko część godzin poświęcona jest zagadnieniom związanym z ochroną przyrody. 
Profil przyrodniczy ujmuje ochronę przyrody i środowiska jako naukę, ideę i działalność. Zajmuje się także rozwojem idei i metodami ochrony przyrody w Polsce i na świecie oraz obejmuje zasady i sposoby turystycznego użytkowania obszarów chronionych. Profil ekologiczny zajmuje się funkcjonowaniem ekosystemów naturalnych, relacjami człowiek - środowisko, podejmuje tematykę ochrony różnorodności gatunkowej i genetycznej, zawiera elementy ekorozwoju i sozotechniki.

Trzecia grupa tematyczna obejmuje szeroko rozumiane walory przyrodnicze i ich wykorzystanie w turystyce. W skład poruszanych tu zagadnień wchodzą: podział, charakterystyka oraz rozmieszczenie walorów przyrodniczych na terenie kraju.

Zajęcia kameralne poruszające zagadnienia ochrony środowiska obejmują 160 obligatoryjnych godzin dydaktycznych, co stanowi $6,4 \%$ wszystkich tego rodzaju zajęć.

Jedną z ważniejszych części edukacji przyrodniczej studentów geografii turyzmu i hotelarstwa są zajęcia praktyczne. Odbywają się one w trakcie kursu strażnika ochrony przyrody i kończą się uzyskaniem odpowiednich uprawnień. Obejmują także ćwiczenia terenowe specjalnościowe w parkach narodowych i krajobrazowych, gdzie w ciagu czternastu dni ( 84 godz.) studenci piszą pracę kontrolną, będącą jednym $\mathrm{z}$ elementów zaliczenia. Większość z wykonanych dotychczas prac charakteryzuje się dużymi walorami poznawczymi i dydaktycznymi. Zakres tematyczny prac przedstawia tab. IV, a zakres terytorialny rys. 1 .

Celem ćwiczeń terenowych jest kompleksowe zapoznanie studentów ze strukturą organizacyjna, zadaniami i funkcjami parku narodowego (krajobrazowego). W trakcie trwania ćwiczeń student zobowiązany jest do:

- aktywnego uczestniczenia we wszystkich pracach na terenie parku (prace porządkowe, organizacyjne, merytoryczne, dydaktyczne itp.),

- zbierania materiałów w celu sporządzenia pracy kontrolnej.

Opiekun praktyk z ramienia instytucji przyjmującej upoważniony jest do organizacji pracy studentów zgodnie $\mathrm{z}$ aktualnymi potrzebami parku.

$\mathrm{Z}$ powyższych zestawień wynika, że kształcenie kadr turystycznych w zakresie ochrony środowiska przyrodniczego traktowane jest w' Uniwersytecie Łódzkim na równi z pozostałymi przedmiotami turystycznymi i stanowi integralną część całego systemu dydaktycznego. Takie podejście nie jest zjawiskiem powszechnym, o czym świadczy „szczupłość” godzin przeznaczanych na ten cel w innych uczelniach.

W czasie tak szybkiego przyrostu powierzchni i form organizacyjnych obszarów chronionych problem ten obecnie nie dotyczy już tylko osób profesjonalnie zajmujących się organizacją turystyki, czy też pracowników parków narodowych, krajobrazowych lub innych obszarów podlegających ochronie. Sta- 
Plan pracy kontrolnej: „Park narodowy (krajobrazowy) jako obszar turystyczny”

Le plan du travail de contrôle: „Le parc national (de paysage) en tant qu'un terrain touristique”

1. Organizacja parku

Miejsce parku w strukturze organizacyjnej zwiazanej z ochroną przyrody w Polsce

Wewnętrzna struktura organizacyjna parku

\section{Charakterystyka parku}

Informacje ogólne

etapy tworzenia parku,

przedmiot ochrony,

powierzchnia, obszary ochrony ścisłej

i czéściowej (rezerwaty),

strefa ochronna,

struktura użytkowania (lasy, łaki, pola, wody...),

struktura wlasności

Położenie

na tle jednostek fizyczno-geograficznych

Polski,

w stosunku do najbliższych aglomeracji

miejskich

Dostępność komunikacyjna parku

na tle sieci drogowej i kolejowej Polski,

ze względu na środek transportu (kolej, autobus, samochód...),

ze względu na rodzaj połączeń (stałe, sezonowe, osobowe, pospieszne....).

czestotliwość polączeń,

przejścia graniczne

\section{Atrakcyjność turystyczna parku, re-} gionu

Walory przyrodnicze

uksztaltowanie powierzchni,

klimat,

wody,

szata roślinna (relikty, endemity, zasięgi

występowania),

szata zwierzęca,

elementy przyrody nieożywionej (grupy

skalne, jaskinie, groty...)

Walory antropogeniczne

muzea, wystawy, miejsca martyrologii,

zabytki architektury i budownictwa,

elementy kultury etnicznej (obrzędy, stroje, festiwale, rękodzielnictwo....)
Walory specjalistyczne

(kajakowe, żeglarskie, wędkarskie, taternickie, speleologiczne...)

Zagospodarowania turystyczne parku

baza noclegowa

schroniska, pola biwakowe... - liczba miejsc noclegowych (stałe, sezonowe) - stopień wykorzystania

baza gastronomiczna

liczba miejsc konsumenckich

baza komunikacyjna

szlaki - rodzaj (piesze, rowerowe, narciar-

skie, wodne...), przebieg, oznakowanie, ranga, dlugość, czas potrzebny do przejścia, stopień trudności, uklad szlaków, gęstość,

punkty węzlowe

ścieżki dydaktyczne

kolejki, wyciągi, nartostrady...

parkingi

infrastruktura towarzysząca

punkty widokowe

bramy wejściowe

punkty informacji turystycznej, tablice informacyjne...

\section{Ruch turystyczny}

Wielkość ruchu turystycznego (np. na podstawie rejestracji sprzedaży biletów)

Rodzaj ruchu turystycznego (turystyka indywidualna, grupowa, pobytowa, wędrowna, wycieczkowa...)

Sezonowość ruchu turystycznego, częstotliwość odwiedzin

Obszary penetracji parku.

5. Funkcja turystyczna na tle innych funkcji parku, zagrożenia ekologiczne parku

Wpływ ruchu turystycznego na środowisko naturalne parku.

Wpływ innych elementów na degradację środowiska naturalnego parku.

Konflikty funkcji

Świadomość ekologiczna ew. mieszkańców parku

6. Publikacje o tematyce turystycznej dotyczące parku

Ź r ó d ł o: Opracowanie własne autora. 
je się on coraz bardziej powszechnym elementem rzeczywistości i jako taki dotyczy całości polskiego społeczeństwa. Dlatego też w najbliższej przyszłości należy odpowiedzieć na kilka zasadniczych pytań, a odpowiedzi i wypływające z nich wnioski jak najszybciej wprowadzić w życie.

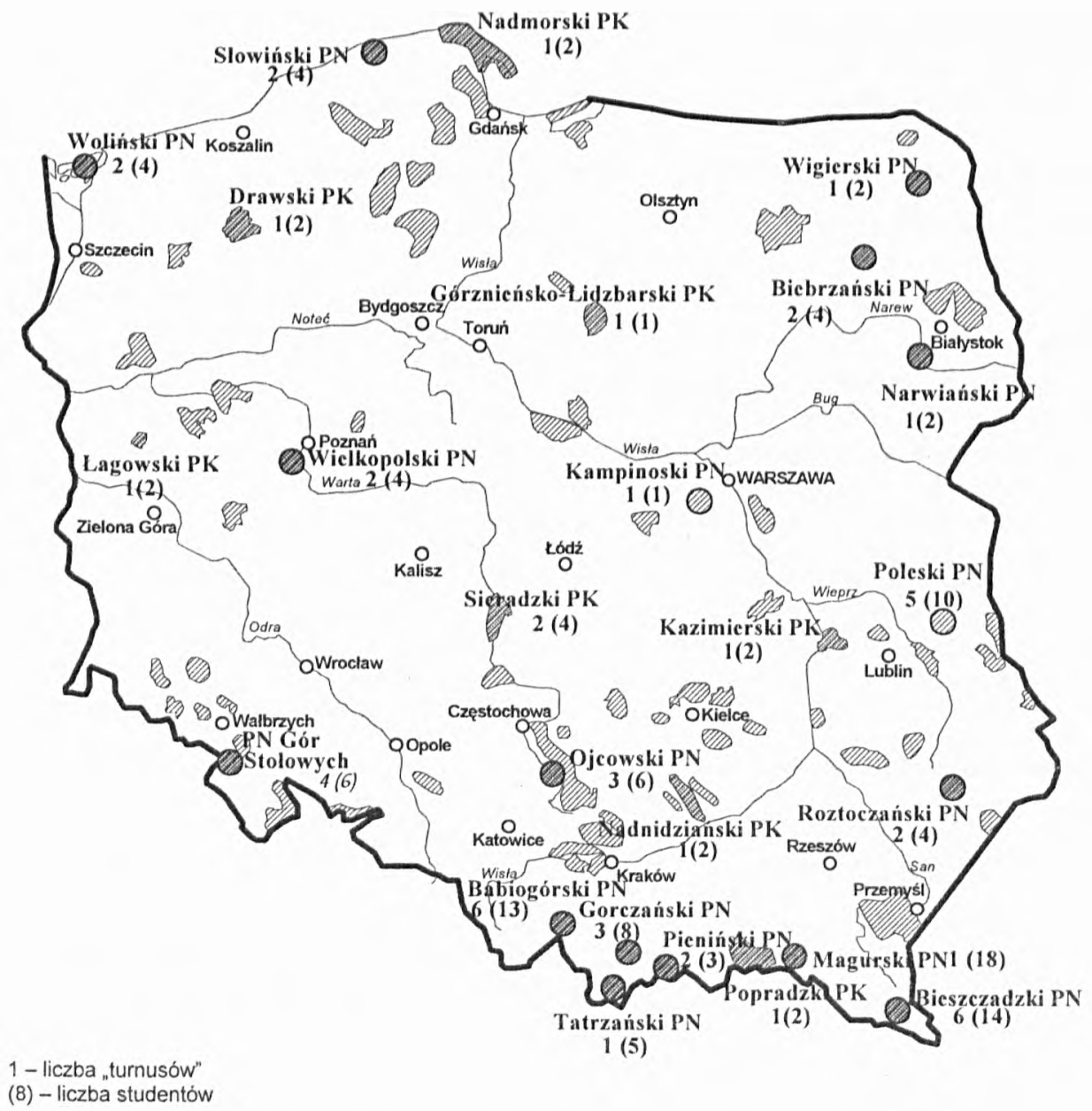

Rys. 1. Miejsca odbywania ćwiczeń terenowych specjalnościowych w parkach narodowych i krajobrazowych studentów I roku geografii turyzmu i hotelarstwa

Dessin 1. Les lieux où se tiennent les exercices sur les terrains des parcs nationaux et ceux de paysage, dans lesquels prennent part les étudiants de la première année en geographie du tourisme et de l'hôtellerie 
Pytania do dyskusji:

Jaki jest stan kształcenia (nauczania) w zakresie ochrony przyrody w polskim szkolnictwie (nie tylko na poziomie wyższym)?

Czy moda na „ekologię” (także w turystyce) może być bazą dla nauczania racjonalnego stosunku do środowiska przyrodniczego?

Czy istnieje potrzeba ksztalcenia kadr turystycznych w zakresie ochrony przyrody? Jeżeli tak, to jakie treści programowe powinno zawierać to kształcenie?

Czy pomimo konfliktu funkcji istnieje potrzeba kształcenia gospodarzy (kadr) obszarów chronionych w zakresie obsługi ruchu turystycznego?

Jakie są szanse osiągnięcia porozumienia między gospodarzami obszarów chronionych a organizatorami turystyki?

Czy edukacja w zakresie ochrony przyrody (środowiska) i obsługi ruchu turystycznego może stać się podstawą optymalnego wykorzystania obszarów chronionych dla potrzeb turystyki?

Mgr Bogdan Wlodarczyk

Katedra Geografii Miast i Turyzmu

Uniwersytet Lódzki

al. Kościuszki 21

90-480 Lódź
Wplynęło: 8 kwietnia 1997 r. 